\title{
19. Emotions, love, and sexuality in committed relationships
}

\author{
Karl Lenz and Marina A. Adler
}

\section{INTRODUCTION}

In contemporary societies, love and sexuality are probably most strongly associated with marriage and with other couple relationships. Thus, it may seem surprising that, until recently, love and sexuality have remained at the margins of family studies (Lenz 2009). Love, which was described by Austrian writer Musil (1989, p. 1219) as the most talkative emotion of all, and which has been written and sung about ad infinitum, may have been too 'corny' or fluid a concept to invite scientific analysis. The reluctance to consider sexuality as a sociological topic may stem from its association with the intimate sphere, which was deemed an area that other disciplines, such as psychology, were better suited to investigate.

In everyday life, love and sexuality appear to be strongly connected. Yet within sociological discourse, emotion and sexuality belong to separate research areas. In this overview, we introduce both strands of literature, trace the origins of these concepts and their definitions, and summarise sociological studies on the topic of love (and emotions) and sexuality. We focus on love and sexuality in committed relationships, which are defined here as long-term relationships, such as marriage, cohabiting unions, and stable living-apart-together relationships (Schwartz et al. 2013). The most common relationship form is the couple, which can be composed of partners with any gender identity and sexual orientation. In Europe, the expectation that couples will practise monogamy - including serial monogamy - remains strong, even though this norm may be violated, and forms of consensual non-monogamy (for example, polyamory) are also practised (Boehm 2012; Sheff and Tesene 2015). Biographies in which the partners meet at a young age and remain in their first relationship for life are becoming rare. Thus, individuals may enter a series of successive relationships over their life course, which may be marital or non-marital unions.

\section{EMOTIONS AND EMOTION WORK}

Love, and other emotions such as jealousy, grief, and anger, have been largely neglected by sociology, apart from in some preparatory work by the sociological classics (e.g., Simmel 2004). It was not until the 1970s that the topic of emotions became more prevalent in sociology (Stets and Turner 2007, 2014). Historically, emotions were considered 'intraindividual', and, therefore, unsuitable for sociological analysis. Moreover, even psychology has had a distant relationship to emotions (Ulich and Mayring 2003). Both of these disciplines have struggled with this topic because they are rooted in the predominant scientific image of humans as rational beings. Consequently, emotions were considered to be merely an irrational relic (Plamper 2012). This simplistic dichotomy between mind and feeling has lost much of its 
persuasiveness today. The clear limits of this perspective and the fragility of the rationality argument have led to a rediscovery of feelings as a scientific topic. Recently, numerous fields of research beyond that of personal relationships have begun to take emotions into account (Korte 2015). Indeed, interest in examining emotions has grown beyond sociology, and includes all of the social sciences and humanities (e.g., Frevert 2009; Matt and Stearns 2014).

In order to facilitate this scholarly interest in emotions, the organism model, which emerged at the beginning of emotions research (e.g., through the studies of Charles Darwin), had to be critiqued and rejected. According to this model, emotions are relegated to the realm of the physical human body, and are understood as genetically pre-programmed biophysiological processes. The social sciences and the humanities agree that emotions involve a coordinated interaction of physical and mental components (Gebauer et al. 2017), and encompass (peripheral) physiological responses, such as sweating and rapid heartbeat. These physical reactions often occur unintentionally, and the subjective feeling exists even if it is not verbally communicated (e.g., in newborns). From a socio-cultural perspective, however, emotions transcend biological processes. Constructivist emotions research shows that emotions are also socio-cultural phenomena (Gordon 1990). While this perspective does not deny the possibility of universal feelings and universally assigned patterns of expression (Scheve 2017), it insists that reducing social and cultural factors to the mere activation of already established emotional components is inadequate. Rather, proponents of this perspective contend that socio-cultural factors significantly affect the primary development of subjective feelings and facial expressions. Thus, emotions are considered to be interwoven into social contexts, and are generated and shaped in social processes that provide their specific meanings. It is further posited that emotional qualities are formed in historically contingent discourses and social practices.

Emotion work refers to the deliberate regulation of emotions. According to Hochschild (1979), 'surface-acting' refers to the emotional expression considered appropriate, while 'deep-acting' - or 'emotion work' - involves a corresponding change in the feeling itself. Emotion work can involve 'evoking' or 'suppressing' a feeling, and is guided by 'feeling rules', which are connected to cultural discourses. Hochschild (1983) provided several examples of emotion work in professional and family settings. The study of emotion work is now a large and productive area in couples research (Levenson et al. 2014).

Emotions and emotion work in committed relationships are gendered. Erickson (2005) observed that for women, the performance of emotion work is primarily perceived as instrumental work; while for men, the willingness to engage in emotion work reflects the particular attachment to a partner. Kaufmann (2007) showed that anger in everyday interactions arises from gendered standards of cleanliness and from disagreements over the division of labour. Furthermore, certain relationship stages, such as separation, are strongly associated with emotions (Kayser and Rao 2006). These emotions may include grief and anger; but also guilt and self-loathing, feelings of failure and loneliness, as well as euphoria. Both parts of the separation process - i.e., leaving and being abandoned - produce emotions.

The feeling of jealousy is particularly strongly associated with intimate relationships (Ben-Ze'ev 2010). Simmel (1992 [1908]) pointed to the potentially destructive effects of jealousy. It is well documented that feelings of jealousy can have serious negative consequences, such as motivating assaults and homicides (Puente and Cohen 2003). While jealousy is considered a universal feeling, it takes different forms and results from diverse actions in specific societies and historical eras (Reiss 1986). This variation is based on ideas of exclusivity and ownership enshrined in relationship norms and related power relations. Stearns (1989) and 
Clanton (1989) examined the changes in cultural norms associated with jealousy. However, little is known about how jealousy plays out in everyday life. Empirical studies on polyamory (e.g., Pieper and Bauer 2014) can help address this research gap. In this relationship model, which is based on the premise that love for and intimacy with multiple partners should be lived openly and consensually, coping with jealousy is inevitable.

\section{WHAT IS LOVE?}

Philosophical contemplations of love in Western intellectual history, such as Plato's Symposium featuring speeches on eros, suggest that love is not limited to couples. This thought is clearly reflected in Christian discourse, in which pure love that is free of desire and directed at God is central. In late antiquity, a 'ban on lust' (Le Goff 1995) was propagated by Augustine. As a result, love and sexual desire became opposites, and the juxtaposition of 'high' and 'low' love gained popularity in cultural history (Lenz et al. 2013). Despite the differences in the objects of love - which may include neighbours and material things - attempts have been made to generate a unified concept of love. Demmerling and Landwehr (2007) identified three structural features of love: (1) the desire to be close to the object; (2) being focused on the lover's needs and on what they yearn for; and (3) the lack of rational justifications for the choice. While this broad conceptualisation of love is also found in sociology (e.g., Simmel 2004), it is mainly applied to committed relationships (Burkart 2018).

The question of whether love is an emotion at all has been widely discussed (Felmlee and Sprecher 2007). The arguments against this being the case are that: (1) love is merely a cultural form of a primary sexual aspiration; (2) love, like happiness, is a meta-emotion that enhances feelings, and is not like basic emotions, such as fear, which are associated with universal facial expressions; and (3) love is mainly a goal-oriented motivational state. In addition, if love continues to be perceived as a feeling, it may primarily be so because of its accidental and unintentional character (Demmerling and Landwehr 2007), and because it aligns with everyday views (Fehr and Russell 1984). However, much of the sociological literature on love focuses not on the feeling, but on the relationship that is characterised by it (Seebach 2017).

There are also different views on the question of whether love is a universal emotion. For example, Tomlinson et al. (2018, p. 407) wrote:

Romantic love seems to be a universal phenomenon, appearing in every culture for which data are available ... and in every historical era ... Analogs to romantic love are found in a wide variety of higher animal species, and love may well have played a central role in shaping human evolution.

Social psychological attempts to capture love empirically are also grounded in this perspective. For example, Rubin (1970) proposed scales that distinguish between 'loving' and 'liking'. Moreover, Hendrick and Hendrick (1986), following the Canadian sociologist Lee (1973), differentiated six forms of love: 'eros' as a romantic sensual pleasure; 'ludus' as a playful type of love; 'storge' as a friendship-based love; and three other secondary types ('mania', 'pragma', and 'agape'). Also common in this literature are efforts to draw a distinction between passionate and companionate love (Sprecher and Regan 1998). Sternberg's (1986) theory assumes that love includes three components (intimacy, commitment, and passion), which in different combinations result in various forms of love. 
In contrast to this essentialist view, sociology considers love as a culture-bound phenomenon (Plamper 2012). This thesis rejects the centuries-long ethnocentric conception of love as universal (Endleman 1989). Thus, attention is shifted to observing the love discourse and the social practice of love. Central to this model are the dominant patterns that collectively determine what (real) love is in a given society in a particular historical era. Luhmann's (1986) 'Love as a Passion' examines love as a culture-bound concept. Luhmann argues that the social transformation from a stratified to a functional mode of differentiation produces profound changes in the stock of knowledge. His theoretical and historical investigation describes the emergence of romantic love semantics, in which love and sexuality are linked. For Luhmann, love is a generalised, symbolic medium of communication that facilitates the actually improbable communication within the functional system of intimate relations. His statement that love 'is not itself a feeling, but rather a code of communication' (Luhmann 1986, p. 20) suggests that love is a cultural stock of knowledge that guides how this emotion is expressed and experienced, or can be perceived or pretended. In addition, Luhmann emphasised the close connection between love and sexuality. He argues that 'no communicative system can be devised totally disregarding the physical existence of the communicators within it, and the functional specialization of a media-semantics thus requires that this physical, organic relation also be transformed into symbols' (Luhmann 1986, p. 26). According to Luhmann, symbols are 'symbiotic mechanisms'; and, in the case of love, sexuality is the symbiotic mechanism.

There is widespread agreement that the emergence of romantic love marked a decisive shift in love-related cultural norms in Europe. Romantic love refers to an idealised conception of love that emerged in the literary circles of German romanticism in the late eighteenth and early nineteenth centuries. Tyrell (1987, p. 579) described the central characteristics of romantic love as an 'unconditional preference for a particular individual person' and 'the enthusiastic elevation of precisely this matter to ... maximum relevance'. Overall, however, there is no consensus on the definition of the concept, and scholars often refer to romantic love without defining what is meant.

Since the nineteenth century, romantic love has become a tremendous cultural success (Tyrell 1987). However, the literary idea of romantic love has only gradually influenced the feeling rules for committed relationships - and only in a diluted form. Luhmann has raised the question of whether romantic love still exists in contemporary society, and concluded 'that the semantic content of "romantic" and "romanticism" has been "clandestinely replaced" (Luhmann 1986, p. 160). While most scholars agree that romantic love semantics are undergoing a profound transformation (Lenz et al. 2013), they disagree about the direction and the extent of this change. The different arguments are as follows: romantic love is being replaced by a new love semantic (Giddens 1992); different love semantics are competing or coexisting (Koppetsch 1998); there are basic shifts within the romantic love semantic (Lenz et al. 2013); romantic meanings simultaneously increase and decrease (Scholz et al. 2013); and romantic love is increasing in importance (Beck 1995). This debate is complicated by the inconsistencies in the definitions of romantic love used. In addition, most of the above-mentioned publications on romantic love refer only to heterosexual couples (for an exception, see Gammerl 2013). In this literature, a heteronormative perspective is common, and is often unquestioned (Lenz 2018). Thus, two clearly distinguishable, mutually exclusive genders are assumed, and heterosexual desire is considered 'natural' and 'normal'. In addition, the fact that there are also relationship constellations that include more than two people remains largely unacknowledged. 


\section{Research handbook on the sociology of the family}

Illouz's work examines the transformation of emotions and romantic life through the culture of modernity and capitalism. In Consuming the Romantic Utopia (1997), she describes how commodity capitalism has seized the practices of romantic love. According to Illouz, romantic love has become commodified, and a wide range of goods have been romanticised as expressions of 'true love'. Thus, romantic love has become part of the process of capitalist exploitation. Illouz (2009) also traces the rise of 'homo sentimentalis', as well as the emergence of psychology as the authority for interpreting emotions. More recently, she examined changes in suffering related to love, and the negative effects of sexual freedom (Illouz 2012, 2018). Illouz argues that these changes situate love in the choice of partners in a free marriage market; in the increased dependency of the modern self on recognition in the area of love; in the rationalisation of desire by psychology; in the possibilities of the internet; and in an increasing gap between one's own experiences and medial promises. According to Illouz (2012, 2018), it is above all women who suffer from the contradictory ideals of autonomy and recognition, sexual freedom, and romantic love. However, Illouz could be criticised for the gendered images emerging from this argument.

Although Illouz's focus is on the discourse level, she also incorporates the level of social practice into her work. This is done to an even greater extent by Swidler (2003), who investigates 'narratives of love' in everyday life. In her interviews, romantic love and a more practical, 'real' love became visible. Similarly, Bethmann (2013), analyses love in the multiple moments of its interactive production, and found that couples do not have a uniform love concept. Studies connecting love as a cultural pattern with love as a social practice remain rare (Lenz 2009).

\section{SEXUALITY AND SOCIAL CHANGE}

For a long period of time, sexuality was almost exclusively examined in relation to fertility and was only studied within the area of sexology (Sigusch 2008), which was dominated by a medical perspective. Early sexologists (Krafft-Ebing 1984 [1886]) understood sexuality mainly within the context of reproduction (Stein-Hilbers 2000). Reproduction was considered the biological goal of sexuality, and the instinctual sex drive was seen as necessary for the survival of humankind. Only sexuality that serves reproductive purposes - meaning coitus - and that takes place within the context of marriage was regarded as 'natural sexuality' (Jackson 2000). Every other form of sexuality was dismissed as a 'perversion' or an 'aberration'. Closely related to this view were essentialist assumptions about the nature of women and men. The sex drive was seen as the key feature in binary gender identity: i.e., the active, sexually driven man versus the passive, sexually disinterested woman.

By the 1970s, the dominant medical perspective had been rejected, and sexuality came to be regarded as a social phenomenon. In the course of this shift, the instinctual sex drive also lost its status as a guiding concept (Schmidt 2014). Today, sexuality is mostly seen as a resource and as a historically changing phenomenon (Benkel and Akalin 2010; Lewandowski and Koppetsch 2015). While sexology facilitated this opening towards the social sciences, the impetus for the broadening of perspectives came from external sources: (1) the newly formed field of Women's and Gender Studies deals extensively with sexuality as linked to the gender hierarchy; (2) Foucault's discourse analysis has subjected the scientific study of sexuality, including Freud's psychoanalysis, to a far-reaching critique, and has opposed the repression 
hypothesis (Foucault 1977); and (3) works based on Symbolic Interactionism point to the social construction of sexual reality, and question the assumption that sexuality is bound to a sex drive (Davis 1983). Especially noteworthy is the concept of the sexual script by Gagnon and Simon (1973).

Lautmann's (2002, p. 25) definition of sexuality as a 'pleasurable encounter of bodies' acknowledges the body as the central and indispensable characteristic of sexuality; positing that in a sexual interaction, the body is the object of desire, as well as the centre of one's own experience. This definition leaves open the question of whether sexuality takes place within or outside of committed relationships, and of what forms of pleasurable experiences are being practised. Moreover, the gender and the number of those present are not specified. This definition may need to be expanded because sexuality is not always tied to the physical presence of another person and the experience of pleasure with one's own body is sufficient to be defined as sexuality. The term 'solo sex' has replaced that of masturbation (Böhm and Matthiesen 2017). This broad understanding of sexuality should be linked to society's norms of legitimate sexuality, and should include both the social context in which sexuality occurs and the sexual practices used. All societies have established rules regarding what is sexually appropriate, and individuals learn these cultural norms as part of the socialisation process. There are differences in the scope of social control exercised over sexuality, especially of female and same-sex sexuality.

Sex research is strongly centred on individuals. Although sexual activities (and fantasies) often involve the co-presence of at least - and usually only - two persons, the focus of research is not the sexual interaction, but the individual person. This is the case for both quantitative and qualitative studies. Even though 70 years have passed since Kinsey et al.'s (1948, 1953) pioneering studies were conducted, reservations about sexuality as a survey subject remain common. For some European countries, survey data on sexuality are available for the adult population, including some data from repeated cross-sectional surveys (e.g., France, the United Kingdom, Finland) (Bajos et al. 2008; Mercer et al. 2013). But this is not the case for all countries, and some have only recently started to collect data on this sensitive topic (for example, Germany) (Haversath et al. 2017; Matthiesen et al. 2018).

Most sex research provides only a snapshot of an individual's current sexual life (Sprecher et al. 2018). Both longitudinal studies and studies that take a longer-term life course perspective are lacking (Lodge 2015). An exception is the German 'Beziehungsbiografie-Studie', in which the (previous) relationships and sexual experiences of 30, 45, and 60 year olds in two German cities were compared (Schmidt et al. 2006). Qualitative studies (for example, see BZgA 2017) may also overcome the limitations of cross-sectional studies. Applying a life course perspective can clarify the effects of age and relationship duration, and how sexuality changes with relationship status. For example, an individual's sexual orientation, as well as their openness to casual and non-monogamous sex, may change over time (Carpenter 2015).

The transformation of sexuality over the last six decades is a topic that has received widespread public and academic attention. It was common to refer to a 'sexual revolution' in the late 1960s and early 1970s. The women's and the LGBTQA+ movements, the popularity of sex educational books and films, the triumph of the pill, the increase in sex scenes in movies, and the release of pornography for adults have been cited as evidence of a radical shift in sexuality. However, contemporary historical research (e.g., Herzog 2005) has since found indications that the sexual revolution is a myth (Eder 2015). Without denying that massive changes in sexuality have occurred in general, and in terms of the sexual liberation of women 
in particular, it is shown that these changes were part of a longer-term process that started in the 1940 s, or even earlier. In addition, the use of the revolution metaphor has been criticised, because its polarity of oppression and liberation is considered inappropriate for understanding this complex historical phenomenon.

Although these changes involved a long-term process, a 'transformation of intimacy' (Giddens 1992) did occur, resulting in what Giddens called a 'plastic sexuality'. This term refers to a flexible sexuality that has freed itself from reproduction and can take on different forms. Sexuality also gained a high degree of biographical relevance, and is now integrated into the reflexive project of the self. The clear distinction between 'normal sexuality' and 'perversion' has largely disappeared. A narrow and rigid understanding of sexual normality has been replaced by a wide range of choices and arrangements. Particularly noteworthy is the advanced normalisation of LGBTQA+ sex after long being criminalised, pathologised, and stigmatised in western European countries (Lautmann 1993). This has also been the case for sexual practices. Solo sex has become a type of pleasuring that is also practised alongside or combined with sex in committed relationships (Böhm and Matthiesen 2017). The spectrum of sexual practices in relationships now includes oral and anal practices, the use of sex toys, and BDSM practices. However, heterosexuality dominates. In the British National Survey of Sexual Attitudes and Lifestyles (Natsal-III), approximately 97 per cent of women and men aged 16 to 74 identified as heterosexual (Mercer et al. 2013). The French survey (Bajos et al. 2008) and the German pilot study (Cerwenka and Brunner 2018) reported similarly high percentages. This identification does not exclude the possibility of having other sexual experiences. However, discrepancies between sexual identity and sexual behaviour are more common among LGBTQA+ individuals (Hayes et al. 2012).

The decisions about both heterosexual and LGBTQA+ sexual practices have shifted to the individual or to the couple level. Supported by the liberal discourse of the 1960s and 1970s and the self-determination discourse in the 1980s, a 'negotiated morality' (Schmidt 2014) in sexual activities was established that involves evaluating how sexual acts and practices come about. This requires a high degree of sensitivity to the wishes and the appropriate boundaries of the participants and consent before and during a sexual interaction. Transgressions infringe upon the ritual order, violate boundaries, and can lead to sexual assault. However, the new sexual options are not necessarily used by every couple or by every person. Thus, there are no indications of a 'sexual decay', as is frequently feared in conservative circles; nor of a boundless sexual zest for experimentation. Couples negotiate their sexual scripts, and decide which ones are right for them.

This transformation process has produced profound changes in female sexuality. For much of the twentieth century, a double standard persisted that allowed men to have pre- and extramarital sexual experiences, while denying them to women by threatening them with a ruined future. This double standard resulted in marriages between sexually experienced older men and completely inexperienced young women. This pattern has fundamentally changed in Europe, except among some immigrant groups. Thus, sexuality has become a more self-determined experience for women. Some studies report that young women may even have more sexual experiences than men of the same age (Dekker and Matthiesen 2015). These findings could point to a convergence of women's and men's sexual experience. Thus, Kimmel (2008, p. 287) used the term 'masculinization of sex' to refer to 'the pursuit of pleasure for its own sake, the increased attention to orgasm, the multiplication of sexual partners, the universal interest in sexual experimentation, and the separation of sexual behavior from love'. 
Despite these enormous changes in the sexual lives of women, some gender differences persist. Differences in sexual attitudes have become less pronounced, with men being only slightly more sexually permissive than women (Klein and Brunner 2018). In adulthood, men report having more sexual activity and more partners than women (Haversath et al. 2017). It is, however, possible that these differences are exacerbated by the effects of social desirability (Alexander and Fisher 2003). Although double standards in the assessment of sexual activities by gender have been significantly reduced, they have not disappeared (Peterson and Hyde 2010; Plagge and Matthiesen 2017). The most striking gender differences continue to relate to the use of sex work services and pornography (Dekker and Matthiesen 2015). These gender differences persist because sexual interactions are associated with different risks for women and men. Unwanted pregnancy poses a risk for women's bodies and lives, and the possibility of sexual assault is mainly a danger for all those who identify as women.

In all European societies, there has been a strong liberalisation of youth sexuality (Schmidt 2014). Starting with the early 1950s birth cohorts, the age of sexual debut has decreased (Dekker and Matthiesen 2015). Massive shifts can also be observed in the commencing of sexual interactions within committed relationships (Bozon 2001). In the 1950s, at least the promise of marriage was necessary for many women to engage in sexual relations. Today, a couple's first sexual interactions tend to occur at the beginning of a committed relationship. Kaufmann (2002) uses the term 'autonomization of the sexual' when a sexual encounter marks the beginning of a potential relationship. For a growing number of couples, but not all, the 'first time' marks the possible beginning of a relationship, regardless of whether the partners have known each other for a longer time, or have just met (Lenz 2005). For the majority of couples, the first sexual interaction coincides with the formation of the couple relationship, although some couples wait until sufficient emotional trust has been established by both sides (Heßling and Bode 2016).

Cross-national studies have shown that sexual exchanges predominantly occur in committed relationships (Laumann et al. 1994; Schmidt et al. 2006). This appears to be the case for most women, regardless of their sexual orientation, and most heterosexual men. Gay men are less likely to have stable relationships, and they often live in open relationships that include sexual contacts with other men (Bochow et al. 2008; Peplau and Fingerhut 2007). Casual sex among heterosexuals mainly occurs among single people in the dating phase, and is often a strategy for finding a (new) long-term relationship (Garcia et al. 2015). The availability of mobile hook-up applications for smartphones, such as Tinder, have (to date) not led to increased casual sex practice in Europe. In the United States, the hook-up culture and 'friends with benefits' relationships seem to be much more widespread, especially at universities (Bisson and Levine 2009; Plagge and Matthiesen 2017).

As a hegemonic pattern of orientation, monogamy - which is also referred to as mono-normativity (Pieper and Bauer 2014) - is practised by most couples. This tendency is also reflected in people's attitudes. Despite the liberalisation trends, levels of acceptance for sex outside of marriage and for having a large number of sexual partners are low among women, and are even lower among men (Klein and Brunner 2018). Nevertheless, there are violations or rejections of the monogamy norm. In a survey conducted in Germany (Haversath et al. 2017), 21 per cent of men and 18 per cent of women reported ever having sexual contacts outside of their committed relationships; with 8 per cent of men and 6 per cent of women indicating that these contacts had occurred in their current relationship. Similar results, but with greater gender differences, are reported for the United States (Carr 2010). There are different 
forms of external sexual contacts, such as a one-time occurrence or, primarily in men, contacts with prostitutes. Other forms of sexual contact include a new or transitional relationship during the phase of relationship dissolution, or regular external contacts or a secondary sexual relationship within a primary relationship. Most of these contacts occur in secret, or under a 'don't ask, don't tell' policy (Sheff and Tesene 2015). Additional forms of sexual contact are difficult to quantify, such as openly lived non-monogamous relationships; e.g., polyamory or swinging. Overall, however, the available evidence indicates that serial monogamy continues to be lived by most couples. The findings of the German repeat survey of students even suggest that fidelity and exclusivity have become increasingly important to German adults in the last three decades (Dekker and Matthiesen 2015). This trend has also been reported in other countries (Treas et al. 2014).

The frequency of sexual activities is highest at the beginning of a relationship, and tends to decrease over time. This does not occur in a linear fashion (Bozon 2002), but rather in leaps and bounds. The birth of the first child can lead to significant changes (Ahlborg et al. 2005; Hyde et al. 1996). This decline is often associated with reduced erotic tension. Bozon (2001, p. 16) contrasts this pattern with the ritual quality of sexuality, noting that the frequent sex at the beginning 'is entirely dedicated to the construction of the couple'; while later sex becomes a 'maintenance ritual' that 'does not require the same high frequency of intercourse as a foundations building activity' (Bozon 2001, p. 17). In the initial stages of a heterosexual relationship, there are also high levels of convergence and reciprocity between the partners. As the relationship continues, the sexual interest of and the initiative taken by the female partner in particular tend to decrease markedly (Kontula and Haavio-Mannila 1995). There are significant differences in sexual activity levels depending on the sexual identities of the couples. Sexual activity appears to be least frequent among lesbian couples (Peplau and Fingerhut 2007). However, the available studies may not adequately capture lesbian sexuality, which is less genital-centred.

\section{CONCLUSION AND SUGGESTIONS FOR FUTURE RESEARCH}

In this chapter, we provided an overview of key definitions and summarised the sociological studies on love (and emotions) and sexuality in committed relationships. We described the debates about whether love is a universal or a culturally specific phenomenon, explained the relevance of romantic love semantics, and discussed the recent transformation of the understanding of love. We also observed that the sexuality of couples has changed significantly, and that these changes in sexuality began before the start of the so-called 'sexual revolution'. In reconstructing these cultural changes, we showed how an era of liberated sexuality and established ethical sexual negotiation has shaped the sexual behaviour of couples. We recommend bringing the two largely independent research fields of emotion and sexuality closer together. In Western societies, love and sexuality are closely related, and are regarded as mutually causal. This correlation between emotionality and sexuality (McNulty et al. 2016) should be examined further in order to determine whether, as expected, there is bi-directionality. In general, sex research has to include emotional experiences, and emotions research should consider sexual interactions as the basis for emotions. 
A wide range of lifestyles extending beyond heterosexuality and committed relationships are now receiving considerable attention in sex research, and without being subjected to assumptions about whether these behaviours are 'normal'. However, this understanding does not apply to family studies, which continue to focus on heterosexual, committed relationships (for an exception, see Maier 2007). This restricted focus limits our understanding of the multitude of existing life plans, and prevents us from learning more about heterosexual committed couples through comparisons with same-sex and non-monogamous relationships. United States research has made more progress in closing this gap than research in Europe (Diamond and Blair 2018).

In addition, because most sex research focuses on individuals in couple relationships, it tends to privilege individual sexual activities or individual emotional experiences. More attention should be paid to the social dimension of these behaviours, given that they are always happening in an exchange with another person in a committed relationship. Sociology, which claims the social as its subject matter, could make a significant contribution to this area. In particular, script theory shows that couples build their interpersonal scripts for their own sexuality based on their previously acquired intrapersonal scripts, and in line with cultural norms. Emotions are not simply the internal processes of a single entity; rather, emotions are produced by the dynamics within the relationship, and they are continuously interpreted and managed in social exchanges.

A notable deficit of current emotions research is that it mainly provides snapshots. Little is known about whether and, if so, how emotions change over time in a personal relationship. How are emotions embedded in the relationship history of a couple or in the relationship biographies of individuals? While some authors delineate a period of falling in love, they do not examine the changes in love relationships over time (Riela et al. 2010). Following Simmel, we might ask whether love is sustainable over the long term, or whether it needs to be supported by a secondary emotion, such as fidelity (Seebach 2017). In addition, we do not yet know whether and, if so, how love ideals differ in successive relationships. Such issues are relevant not just for the study of emotions, but for efforts to understand sexuality.

\section{REFERENCES}

Ahlborg, T., L.G. Dahlöf, and L.R.M. Hallberg (2005), 'Quality of the intimate and sexual relationship in first-time parents six months after delivery', Journal of Sex Research, 42 (2), 167-74. doi:10.1080/ 00224490509552270.

Alexander, M.G. and T.D. Fisher (2003), 'Truth and consequences: Using the bogus pipeline to examine sex differences in self-reported sexuality', Journal of Sex Research, 40 (1), 27-35. doi:10.1080/ 00224490309552164.

Bajos, N., M. Bozon, and N. Beltzer (2008), Enquête sur la Sexualité en France: Pratiques, Genre et Santé, Paris: Découverte.

Beck, U. (1995), 'Love, our secular religion', in U. Beck and E. Beck-Gernsheim (eds), The Normal Chaos of Love, Cambridge: Polity Press, pp. 168-221.

Ben-Ze'ev, A. (2010), 'Jealousy and romantic love', in S.L. Hart and M. Legerstee (eds), Handbook of Jealousy, Oxford: Wiley-Blackwell, pp. 40-54.

Benkel, T. and F. Akalin (2010), Soziale Dimensionen der Sexualität, Gießen: Psychosozial-Verlag.

Bethmann, S. (2013), Liebe - Eine soziologische Kritik der Zweisamkeit, Weinheim: Beltz Juventa.

Bisson, M.A. and T.R. Levine (2009), 'Negotiating a friends with benefits relationship', Archives of Sexual Behavior, 38 (1), 66-73. doi:10.1007/s10508-007-9211-2. 
Bochow, M., A.J. Schmidt, and S. Grote (2008), Schwule Männer und HIV/AIDS. Lebensstile, Szene, Sex 2007, Eine Befragung im Auftrag der Bundeszentrale für gesundheitliche Aufklärung (Aidsforum $D A H, B d, 55)$, Berlin: DAH.

Boehm, K. (2012), Praktiken der Polyamorie. Über offene Beziehungen, intime Netzwerke und den Wandel emotionaler Stile, Vienna: Institut für Europäische Ethnologie.

Böhm, M. and S. Matthiesen (2017), 'Solosexualität? - Selbstverständlich!', in Bundeszentrale für gesundheitliche Aufklärung (ed.), Sexualität von Studierenden im Internetzeitalter, Köln, BZgA, pp. 108-31.

Bozon, M. (2001), 'Sexuality, gender, and the couple: A sociohistorical perspective', Annual Review of Sexual Research, 12 (1), 1-32. doi:10.1080/10532528.2001.10559792.

Burkart, G. (2018), 'Liebe, historische Formen und theoretische Zugänge', in B. Kortendiek, B. Riegraf, and K. Sabisch (eds), Handbuch interdisziplinäre Geschlechterforschung, Wiesbaden: Springer, pp. 1093-102.

BZgA Bundeszentrale für gesundheitliche Aufklärung (ed.) (2017), Sexualität von Studierenden im Internetzeitalter, Sexuelle und soziale Beziehungen von deutschen Studierenden, Köln: BZgA.

Carpenter, L.M. (2015), 'Studying sexualities from a life course perspective', in J. DeLamater and R.F. Plante (eds), Handbook of the Sociology of Sexualities, Cham: Springer International, pp. 65-89.

Carr, D. (2010), 'Cheating hearts', Contexts, 9 (3), 58-60. doi:10.1525/ctx.2010.9.3.58.

Cerwenka, S. and F. Brunner (2018), 'Sexuelle Identität, sexuelle Attraktion und sexuelles Verhalten Dimensionen sexueller Orientierungen in der Survey-Forschung', Zeitschrift für Sexualforschung, 31 (3), 277-94. doi:10.1055/a-0664-4764.

Clanton, G. (1989), 'Jealousy in American culture, 1945-1985: Reflections from popular culture', in D.D. Franks and E.D. McCarthy (eds), Handbook of the Sociology of Emotions Original Essays and Research Papers, Greenwich, CT: JAI Press, pp. 179-93.

Davis, M.S. (1983), Smut: Erotic Reality/Obscene Ideology, Chicago, IL: University of Chicago Press.

Dekker, A. and S. Matthiesen (2015), 'Studentische Sexualität im Wandel, 1966-1981-1996-2012', Zeitschrift für Sexualforschung, 28 (3), 245-71. doi:10.1055/s-0035-1553700.

Demmerling, C. and H. Landweer (2007), Philosophie der Gefühle. Von Achtung bis Zorn, Stuttgart: Metzler.

Diamond L.M. and K.L. Blair (2018), 'The intimate relationships of sexual and gender minorities', in A.L. Vangelisti and D.T. Perlman (eds), The Cambridge Handbook of Personal Relationships, Cambridge: Cambridge University Press, pp. 199-210.

Eder, F. (2015), 'Die lange Geschichte der "Sexuellen Revolution" in Westdeutschland (1950er bis 1980er Jahre)', in P.-P. Bänziger, M. Beljan, F.X. Eder, and P. Eitler (eds), Sexuelle Revolution?, Bielefeld: Transcript, pp. 25-60.

Endleman, R. (1989), Love and Sex in Twelve Cultures, New York: Psyche Press.

Erickson, R.J. (2005), 'Why emotion work matters: Sex, gender, and the division of household labor', Journal of Marriage and Family, 67 (2), 337-51. doi:10.1111/j.0022-2445.2005.00120.x.

Fehr, B. and J.A. Russell (1984), 'Concept of emotion viewed from a prototype perspective', Journal of Experimental Psychology: General, 113 (3), 464-86. doi:10.1037/0096-3445.113.3.464.

Felmlee, D.H and S. Sprecher (2007), 'Love', in J.E. Stets and J.H. Turner (eds), Handbook of the Sociology of Emotions, New York: Springer, pp. 389-409.

Foucault, M. (1977), Sexualität und Wahrheit, Erster Band, Der Wille der Wahrheit, Frankfurt/Main: Suhrkamp.

Frevert, U. (ed.) (2009), Geschichte der Gefühle, Göttingen: Vandenhoeck and Ruprecht.

Gagnon, J.H. and W. Simon (eds) (1973), Sexual Conduct: The Social Sources of Human Sexuality, New Brunswick, NJ: Aldine Transaction.

Gammerl, B. (2013), 'Queer Romance? Romantische Liebe in den biographischen Erzählungen von westdeutschen Lebens und Schwulen', L'Homme, 24, 15-34. doi:10.7767/lhomme.2013.24.1.15.

Garcia, J.R., S.M. Seibold-Simpson, S.G. Massey, and A.M. Merriwether (2015), 'Casual sex: Integrating social, behavioral, and sexual health research', in J. DeLamater and R.F. Plante (eds), Handbook of the Sociology of Sexualities, New York: Springer, pp. 203-22.

Gebauer, G., M. Holodynski, S. Koelsch, and C. von Scheve (2017), Von der Emotion zur Sprache, Wie wir lernen, über unsere Gefühle zu sprechen, Weilerswist: Velbrück Wissenschaft. 
Giddens, A. (1992), The Transformation of Intimacy: Sexuality, Love and Eroticism in Modern Societies, Cambridge: Polity Press.

Gordon, S.L. (1990), 'The sociology of sentiments and emotion', in M. Rosenberg and R.H. Turner (eds), Social Psychology Sociological Perspectives, New Brunswick, NJ: Transaction, pp. 562-92.

Haversath, J., K.M. Gärttner, S. Kliem, I. Vasterling, B. Strauss, and C. Kröger (2017), ‘Sexual behavior in Germany', Deutsches Ärzteblatt International, 114, 545-50. doi:10.3238/arztebl.2017.0545.

Hayes, J., A.T. Chakraborty, S. McManus, P. Bebbington, T. Brugha, S. Nicholson, and M. King (2012), 'Prevalence of same-sex behavior and orientation in England: Results from a national survey', Archives of Sexual Behavior, 41 (3), 631-39. doi:10.1007/s10508-011-9856-8.

Hendrick, C. and S.S. Hendrick (1986), 'A theory and method of love', Journal of Personality and Social Psychology, $\mathbf{5 0}$ (2), 392-402.

Herzog, D. (2005), Sex after Fascism: Memory and Morality in Twentieth-Century Germany, Princeton, NJ: Princeton University Press.

Heßling, A. and H. Bode (2016), Jugendsexualität 2015: Die Perspektive der 14- bis 25-Jährigen. Ergebnisse einer aktuellen repräsentativen Wiederholungsbefragung, Köln: Bundeszentrale für gesundheitliche Aufklärung.

Hochschild, A.R. (1979), 'Emotion work, feeling rules, and social structure', American Journal of Sociology, 85 (3), 551-75. doi:10.1086/227049.

Hochschild, A.R. (1983), The Managed Heart: Commercialization of Human Feeling, Berkeley, CA: University of California Press.

Hyde, J, J.D. DeLamaler, E.A. Plant, and J.M. Byrd (1996), 'Sexuality during pregnancy and the year postpartum', Journal of Sex Research, 33 (2), 143-57. doi:10.1080/00224499609551826.

Illouz, E. (1997), Consuming the Romantic Utopia: Love and the Cultural Contradictions of Capitalism, Berkeley, CA: University of California Press.

Illouz, E. (2009), Cold Intimacy: The Making of Emotional Capitalism, Oxford: Polity Press.

Illouz, E. (2012), Why Love Hurts: A Sociological Explanation, Cambridge: Polity Press.

Illouz, E. (2018), The End of Love: A Sociology of Negative Relations, Oxford: Oxford University Press.

Jackson, M. (2000), 'Sexualwissenschaften und die Universalisierung männlicher Sexualität. Von Ellis über Kinsey zu Masters and Johnson', in C. Schmerl, S. Soine, M. Stein-Hilbers, and B. Wrede (eds), Sexuelle Szenen, Inszenierungen von Geschlecht und Sexualität in modernen Gesellschaften, Opladen: Leske und Budrich, pp. 99-115.

Kaufmann, J. (2002), Der Morgen danach. Wie eine Liebesgeschichte beginnt, Konstanz: UVK.

Kaufmann, J. (2007), Was sich liebt, das nervt sich, Konstanz: UVK.

Kayser, K. and S.S. Rao (2006), 'Process of disaffection in relationship breakdown', in M. Fine and J.H. Harvey (eds), Handbook of Divorce and Relationship Dissolution, Mahwah, NJ: Lawrence Erlbaum, pp. 201-21.

Kimmel, M. (2008), The Gendered Society, New York: Oxford University Press.

Kinsey, A.C., W.B. Pomeroy, and C.E. Martin (1948), Sexual Behavior in the Human Male, Philadelphia, PA: W.B. Saunders Co.

Kinsey, A.C., C.E. Martin, W.B. Pomeroy, and P.H. Gebhard (1953), Sexual Behavior in the Human Female, Philadelphia, PA: W.B. Saunders Co.

Klein, V. and F. Brunner (2018), 'Zwischen Liberalität und Retraditionalisierung. Einstellungen zu sexualitätsbezogenen Themen in Deutschland', Zeitschrift für Sexualforschung, 31 (3), 250-62. doi: 10.1055/a-0664-4322.

Kontula, O. and E. Haavio-Mannila (1995), Sexual Pleasures: Enhancement of Sex Life in Finland, 1971-1992, Aldershot: Dartmouth.

Koppetsch, C. (1998), 'Liebe und Partnerschaft. Gerechtigkeit in modernen Paarbeziehungen', in K. Hahn and G. Burkart (eds), Liebe am Ende des 20. Jahrhunderts, Opladen: Leske und Budrich, pp. 111-29.

Korte, K. (ed.) (2015), Emotionen und Politik, Begründungen, Konzeptionen und Praxisfelder einer politikwissenschaftlichen Emotionsforschung, Baden-Baden: Nomos.

Krafft-Ebing, R. von (1984 [1886]), Psychopathia sexualis. Mit besonderer Berücksichtigung der conträren Sexualempfindung: Eine klinisch-forensische Studie, Munich: Matthes und Seitz.

Laumann, E.O., J.H. Gagnon, R.T. Michael, and S. Michaels (1994), The Social Organization of Sexuality: Sexual Practices in the United States, Chicago, IL: University of Chicago Press. 
Lautmann, R. (1993), Homosexualität: Handbuch der Theorie- und Forschungsgeschichte, Frankfurt/ Main: Campus.

Lautmann, R. (2002), Soziologie der Sexualität. Erotischer Körper, intimes Handeln und Sexualkultur, Weinheim: Juventa.

Le Goff, J. (1995), 'Die Verfemung der Lust', in J. Le Goff (ed.), Liebe und Sexualität, Munich: Boer, pp. 164-80.

Lee, J.A. (1973), Colours of Life: An Exploration of the Ways of Loving, Toronto: New Press.

Lenz, K. (2005), 'Wie Paare sexuell werden, Wandlungsmuster und Geschlechterunterschiede', in H. Funk and K. Lenz (eds), Sexualitäten. Diskurse und Handlungsmuster, Weinheim: Juventa, pp. $113-50$.

Lenz, K. (2009), Soziologie der Zweierbeziehung. Eine Einführung, 4th edition, Wiesbaden: VS-Verlag.

Lenz, K. (2018), 'Liebe und Freundschaft. Annäherung der Semantiken?', in S. Stiehler (ed.), Zukunft der Freundschaft, Berlin: Frank and Timme, pp. 35-64.

Lenz, K., S. Scholz, and S. Dreßler (2013), 'In Liebe verbunden, Paar- und Eltern-Kind-Liebe in der soziologischen Diskussion', in S. Scholz, K. Lenz and S. Dreßler (eds), In Liebe verbunden, Zweierbeziehungen und Elternschaft in populären Ratgebern von den 1950ern bis heute, Bielefeld: Transkript, pp. 11-48.

Levenson, R.W., C.M. Haase, L. Bloch, S.R. Holley, and B.H. Seider (2014), 'Emotion regulation in couples', in J.J. Gross (ed.), The Handbook of Emotion Regulation, New York: Guilford Press, pp. 267-83.

Lewandowski, S. and C. Koppetsch (eds) (2015), Sexuelle Vielfalt und die UnOrdnung der Geschlechter. Beiträge zur Soziologie der Sexualität, Bielefeld: Transkript.

Lodge, A.C. (2015), 'Sexuality in long-term relationships', in J. DeLamater and R.F. Plante (eds), Handbook of the Sociology of Sexualities, Cham: Springer International, pp. 243-59.

Luhmann, N. (1986), Love as Passion: The Codification of Intimacy, Cambridge, MA: Harvard University Press.

Maier, M.S. (2007), Paaridentitäten: Biografische Rekonstruktionen homosexueller und heterosexueller Paarbeziehungen im Vergleich, Weinheim: Juventa.

Matt, S. and P. Stearns (eds) (2014), Doing Emotions History, Urbana-Champaign, IL: University of Illinois Press.

Matthiesen, S. A. Dekker, and P. Briken (2018), 'Pilotstudie zur Erwachsenensexualität in Deutschland. Erste Ergebnisse zu Machbarkeit und Methodenvergleich', Zeitschrift für Sexualforschung, 31 (3), 218-36. doi:10.1055/a-0663-4354.

McNulty, J.K., C.A. Wenner, and T.D. Fisher (2016), 'Longitudinal associations among relationship satisfaction, sexual satisfaction, and frequency of sex in early marriage', Archives of Sexual Behavior, 45 (1), 85-97. doi:10.1007/s10508-014-0444-6.

Mercer, C.H., C. Tanton, P. Prah, B. Erens, P. Sonnenberg, S. Clifton, W. Macdowall, R. Lewis, N. Field, J. Datta, A.J. Copas, A. Phelps, K. Wellings, and A.M. Johnson (2013), 'Changes in sexual attitudes and lifestyles in Britain through the life course and over time: Findings from the national surveys of sexual attitudes and lifestyles (Natsal)', The Lancet, 382 (9907), 1781-94. doi:10.1016/S0140-6736( 13)62035-8.

Musil, R. (1989), Der Mann ohne Eigenschaften, Frankfurt/Main: Fischer.

Peplau, L.A. and A. Fingerhut (2007), 'The close relationships of lesbians and gay men', Annual Review of Psychology, 58, 405-24. doi:10.1146/annurev.psych.58.110405.085701.

Petersen, J.L. and J.S. Hyde (2010), 'A meta-analytic review of research on gender differences in sexuality, 1993-2007', Psychological Bulletin, 136 (1), 21-38. doi:10.1037/a0017504.

Pieper, M. and R. Bauer (2014), 'Polyamorie, Mono-Normativität. Dissidente Mikropolitik - Begehren als transformative Kraft? ', Journal für Psychologie, 22, 1-35.

Plagge, G. and S. Matthiesen (2017), 'Hookup-Culture und One-Night-Stands? Unverbindlicher Sex bei Studierenden', in Bundeszentrale für gesundheitliche Aufklärung'(ed.), Sexualität von Studierenden im Internetzeitalter, Köln: BZgA, 60-76.

Plamper, J. (2012), The History of Emotions: An Introduction, Oxford: Oxford University Press.

Puente, S. and D. Cohen (2003), 'Jealousy and the meaning (or nonmeaning) of violence', Personality and Social Psychology Bulletin, 29 (4), 449-60. doi:10.1177/0146167202250912. 
Reiss, I.L. (1986), 'A sociological journey into sexuality', Journal of Marriage and Family, 48 (2), 233-42. doi:10.2307/352390.

Riela, S., G. Rodriguez, A. Aron, X. Xu, and B.P. Acevedo (2010), 'Experiences of falling in love: Investigating culture, ethnicity, gender, and speed', Journal of Social and Personal Relationships, 27 (4), 473-93. doi:10.1177/0265407510363508.

Rubin, Z. (1970), 'Measurement of romantic love', Journal of Personality and Social Psychology, 16 (2), 265-73. doi:10.1037/h0029841.

Scheve, C. von (2017), 'Die kulturelle Re-Konfiguration des emotionalen Ausdrucksverhaltens', in G. Gebauer, M. Holodynski, S. Koelsch, and C. von Scheve (eds), Von der Emotion zur Sprache, Weilerswist: Velbrück Wissenschaft, pp. 224-57.

Schmidt, G. (2014), Das neue Der Die Das, Über die Modernisierung des Sexuellen, Gießen: Psychosozial-Verlag.

Schmidt, G., A. Dekker, S. Matthiesen, and K. Starke (2006), Spätmoderne Beziehungswelten, Report über Partnerschaft und Sexualität in drei Generationen, Wiesbaden: VS.

Scholz, S., K. Lenz, and S. Dreßler (eds) (2013), In Liebe verbunden, Zweierbeziehungen und Elternschaft in populären Ratgebern von den 1950ern bis heute, Bielefeld: Transkript.

Schwartz, P., B.J. Serafin, and R. Cantor (2013), 'Sex in committed relationships,' in A.K. Baumle (ed.), International Handbook on the Demography of Sexuality, Dordrecht: Springer, pp. 131-65.

Seebach, S. (2017), Love and Society: Special Social Forms and the Master Emotion, London: Routledge.

Sheff, E. and M.M. Tesene (2015), 'Consensual non-monogamies in industrialized nations', in J. DeLamater and R.F. Plante (eds), Handbook of the Sociology of Sexualities, Cham: Springer International, pp. 223-42.

Sigusch, V. (2008), Geschichte der Sexualwissenschaft, Frankfurt/Main: Campus.

Simmel, G. (1992), Soziologie. Untersuchungen über die Formen der Vergesellschaftung, G. Simmel Gesamtausgabe, Band 11, Frankfurt/Main: Suhrkamp.

Simmel, G. (2004), Über die Liebe, in G. Simmel, Postume Veröffentlichungen, Schulpädagogik, Georg Simmel Gesamtausgabe, Band 20, Frankfurt/Main: Suhrkamp, pp. 116-75.

Sprecher, S. and P. Regan (1998), 'Passionate and companionate love in courting and young married couples', Sociological Inquiry, 68 (2), 163-85. doi:10.1111/j.1475-682X.1998.tb00459.x.

Sprecher, S., F.S. Christopher, P. Regan, T. Orbuch, and R.M. Cate (2018), 'Sexuality in personal relationships', in A.L. Vangelisti and D. Perlman (eds), The Cambridge Handbook of Personal Relationships, Cambridge: Cambridge University Press, pp. 311-26.

Stearns, P.N. (1989), Jealousy: The Evolution of an Emotion in American History, New York: New York University Press.

Stein-Hilbers, M. (2000), Sexuell werden. Sexuelle Sozialisation und Geschlechterverhältnisse, Opladen: Leske + Budrich.

Sternberg, R.J. (1986), 'A triangular theory of love', Psychological Review, 93 (2), 119-35. doi:10.1037/ 0033-295X.93.2.119.

Stets, J.E. and J.H. Turner (eds) (2007), Handbook of the Sociology of Emotions, New York: Springer.

Stets, J.E. and J.H. Turner (eds) (2014), Handbook of the Sociology of Emotions, Vol. 2, Dordrecht: Springer.

Swidler, A. (2003), Talk of Love: How Culture Matters, Chicago, IL: University of Chicago Press.

Tomlinson, J.M., A. Aron, and E. Hatfield (2018), 'Romantic love', in A.L. Vangelisti and D. Perlman (eds), The Cambridge Handbook of Personal Relationships, Cambridge: Cambridge University Press, pp. 407-21.

Treas, J., J. Lui, and Z. Gubernskaya (2014), ‘Attitudes on marriage and new relationships: Cross-national evidence on the deinstitutionalization of marriage', Demographic Research, 30 (54), 1495-526. doi: 10.4054/DemRes.2014.30.54.

Tyrell, H. (1987), 'Romantische Liebe. Überlegungen zu ihrer 'quantitativen Bestimmtheit', in D. Baecker, J. Markowitz, and R. Stichweh, Theorie als Passion, Frankfurt/Main: Suhrkamp, pp. 570-99. Ulich, D. and P. Mayring (2003), Psychologie der Emotionen, 2nd edition, Stuttgart: Kohlhammer. 